\title{
Climate change driven disaster risks in Bangladesh and its journey towards resilience
}

\section{Peter Sammonds ${ }^{\circ}$, Mohammad Shamsudduha ${ }^{\circ}$ and Bayes Ahmed ${ }^{\circ}$}

\begin{abstract}
Globally, disasters from natural and anthropogenic hazards or humanitarian crises can reverse development gains and weaken resilience. In recent years, some countries have made significant progress towards building resilience to disaster risks, including those driven by the climate crisis. Bangladesh is a leading example as it is well-known as one of the most vulnerable countries for its multifaceted hazard risks projected to intensity under climate change. Today, the scale of loss of human life from both rapid and slow-onset disasters (e.g. cyclone, flood and drought) is significantly lower than in the 1970s. This remarkable achievement was made possible by independence and the government's proactive investment in development and societal changes through education, technologies and reduction in poverty and inequalities. However, the climate crisis is threatening these development and disaster risk reduction gains. In addition, disaster displacement is a major challenge. The COVID-19 pandemic has unveiled both strengths and weaknesses in our societies. The article argues that disaster management plans need to adapt to the climate crisis and human displacement and reduce migrants' vulnerability while responding to infectious disease transmission.
\end{abstract}

Keywords: natural hazards, climate change, disaster risk reduction, resilience, sustainable development, human displacement, Bangladesh.

Notes on the authors: Peter Sammonds is Professor of Geophysics and Director of the UCL Institute for Risk and Disaster Reduction (IRDR). He works at the interface of natural and social sciences on natural hazard risks, humanitarian crises, disasters and recovery. He works on the issue of Rohingya exodus to Bangladesh and its implications for stability, security and peace in South Asia. Peter was a Commissioner of the UCL-Lancet Commission on Migration and Health, 2017-18. He is the Gender and Intersectionality Ambassador for the UKRI network+ GRRIPP project.

Mohammad Shamsudduha ('Shams') is Associate Professor of Humanitarian Science at the UCL IRDR. Shams' research is centred around the earth's water resources, environment and people. His research interests include hydro-meteorological hazards, water risks and building resilience to global change. For over a decade, Shams worked in South Asia and Sub-Saharan Africa on sustainable water resources development.

Bayes Ahmed is Lecturer in Risk and Disaster Science at the UCL IRDR. He works at the intersection between conflict and disaster with a vision to help to improve the living standards of displaced people and the stateless population. In addition, he is passionate about working with grass-root people to understand their disaster vulnerabilities and producing practical policy recommendations to address their problems.

(C) The author(s) 2021. This is an open access article licensed under a

Creative Commons Attribution-NonCommercial-NoDerivs 4.0 Unported License 


\section{Introduction}

In recent decades, climate-related disasters and extreme weather events (e.g. heavy rainfall, floods, cyclones and droughts) have increased in frequency, intensity and severity driven by anthropogenic warming of the earth's atmosphere and oceans (WMO 2021). Hazards, either natural, biological, technological or anthropogenic in origin, can trigger disasters and dramatically expose the vulnerabilities within which people live in our societies (Kelman 2020). Disaster vulnerability sits at the intersection of poverty, lack of awareness and political instability (Ahmed et al. 2019). Disasters in low- and middle-income countries can set back hard-won development gains for a generation (Davis \& Alexander 2015) while exacerbating pre-existing trends of economic migration from rural to urban areas and internationally (Mbaye 2017).

The 2021 UN Climate Change Conference (COP26) to be held in the UK aims to secure an agreement for global net-zero by mid-century and keep the $1.5^{\circ} \mathrm{C}$ global warming limit within reach, making the Paris Agreement operation ratified in 2016 (COP26 2021). However, the Climate Action Tracker shows that most governments' targets and actions remain highly or critically insufficient to keep to this limit (CAT 2021). Besides, scientists strongly argued that human-induced global heating is responsible for increases in both slow-onset hazards, including temperature rise, drought, sea-level rise, river erosion and land and water salinisation. It also increases the frequency and intensity of rapid-onset hazards such as tropical cyclones, thunderstorms, coastal storm surges, heavy rainfall, floods, landslides and extreme heat (NASA 2020).

It is evident that in a warmer world where the global average temperature in 2020 was $1.2^{\circ} \mathrm{C}$ above the pre-industrial period, adverse impacts are already being felt in the form of increased frequency of extreme weather events (UNDRR 2020). But the effects of climate change are not evenly experienced around the world. Due to its high population density and exposure, South Asia is one of the regions most exposed and vulnerable to climate and hydro-meteorological hazard risks (WMO 2021). Sea-level rise increases disaster risk for coastal communities in the Asian mega-deltas such as the Bengal Delta of Bangladesh, where more than 10 per cent of the country's population are exposed to potential inundation from coastal flooding (Kulp \& Strauss 2019). In addition, coastal inundation/erosion can drive human displacement and migration within and outside the country (Chen \& Mueller 2018).

This article aims to address how global warming will exacerbate disaster risks in a vulnerable region within the Global South and have the potential to drive human displacement. It is through disasters that many people will experience global climate change. Disaster risks coalesce three components: the hazard risk, exposure to the hazard, and vulnerability (Alexander 2018). The capacity to cope is a component 
mitigating the disaster risk. In contrast, resilience is the inverse of vulnerability. However, a paradigm shift occurred when vulnerability and exposure became the most significant components of disaster risk rather than the environmental hazard itself (O'Keefe et al. 1976). We work with the hypothesis that the lack of resilience, poor capacity to cope and inadequate response, coupled with power differentials and resources inequity, ultimately leads to disasters.

This review article will focus on Bangladesh - a low-lying deltaic country in South Asia, criss-crossed by hundreds of rivers. During the monsoon season (May to October), approximately 80 per cent or more of the rainfall falls, and there is little or no rainfall for the rest of the year. Due to its sub-tropical geographic position and extremely flat landscape, Bangladesh is exposed to a wide array of natural hazards and is well-known globally for its frequent disasters. Bangladesh has six major distinct disaster-prone regions according to the National Plan for Disaster Management (NPDM 2021): the coastal zone (19 per cent of the total land area), Barind and drought-prone areas (15 per cent), wetland ecosystem (also known as Haor) and flash flood areas (11 per cent), Chittagong Hill Tracts and landslide hazard (9 per cent), river system and estuaries ( 24 per cent) and urban areas (13 per cent). However, only 8 per cent of the country's total area has been categorised as relatively less hazard-prone (GED 2018).

Bangladesh has a population of approximately 166 million and one of the world's highest population densities (about 1,200 people per $\mathrm{km}^{2}$ ). It has high levels of poverty (World Bank 2021). Bangladesh is considered one of the most vulnerable countries to climate change and associated natural hazard-induced disasters (Eckstein et al. 2021). Furthermore, disaster displacement is an emerging threat. This article examines how Bangladesh has made significant progress in disaster risk reduction (DRR) over the last 50 years since its independence in 1971. Global warming can jeopardise these achievements when combined with other threats, such as the conflict-driven refugee crisis, pandemic and geopolitical instability. Here, we consider the hazards listed in the NPDM 2021 as critical disaster risks to achieving sustainable development. But we focus on the slow-onset hazard of sea-level rise and the climate-related rapid-onset hazards of cyclones and storm surges, floods and landslides identified as critical by HCTT (Humanitarian Coordination Task Team) Nexus Strategy for Climate-related Disasters 2021-2025 (HCTT 2021). We also examine the disaster impacts on human displacement in Bangladesh.

The article combines a desk-top study analysing data from the International Disaster Database, the Global Risk Data Platform, the Bangladesh Flood Forecasting and Warning Centre and the Bangladesh Bureau of Statistics, together with the most up-to-date national and international reports and policy documents related to climate change and disasters. After briefly placing Bangladesh in the global disaster risk context, the article describes both slow- and rapid-onset hazards impacting the country. 
Lessons learnt from previous disaster events are discussed in the DRR framework and features of a resilient country and community. Next, how climate change is influencing the frequency, intensity and magnitude of hazard events is discussed. Then some new evidence on internal migration due to climate-related hazards in Bangladesh is presented. Finally, we have made recommendations for future actions in building resilience to climate-driven natural hazard risks.

\section{Natural multi-hazard risks in Bangladesh}

Globally, the number of recorded natural-hazard induced disasters has increased fivefold since the 1970s, but the total number of disaster deaths has significantly decreased (Figure 1a). Specifically, climate-related disasters and extreme weather events have increased in frequency, intensity and numbers from 3,600 in 1980-99 to 6,700 in 2000-19. Disaster deaths peaked in 1959 at over 2,000,000, while in 2010, they were under 500,000. Progress in DRR through decreasing vulnerability and exposure is attributed to causing the reduction in global disaster deaths as a proportion of the population (Bahadur \& Simonet 2015). The global trends in the number of disasters caused by various natural hazards worldwide from 1950 to 2019 and human fatalities from those disaster events are shown in Figure 1a. Drought, earthquake, extreme temperature, extreme weather, floods, landslide, mass movement, volcanic activity and wildfire are all considered. Here, hazard data from the Emergency Events Database (EM-DAT) are sourced from OFDA/CRED International Disaster Database via Our World in Data (Hannah \& Max 2014). Over the same period, major floods doubled from 1,400 to 3,200 while the number of storms grew from 1,500 to 2,000 (UNDRR 2020). Many of these cases are seen in China and the United States; however, they also impact low-income countries, such as Bangladesh, one of the top ten affected countries with more than 100 catastrophic disasters recorded between 2000 and 2019.

One of the consequences of hydro-meteorological disasters is human displacement. The world has seen a sharply rising trend in human displacement through cross-border migration and internal displacement, with nearly 80 million people being forcibly displaced at the end of 2019 as a result of conflicts, violence, human rights violations and disasters. This can be seen in Figure 1b, which shows the number of human displacements globally from disasters resulting from the same set of natural hazards as in Figure 1a, and conflicts and violence from 2008 to 2019. Data are taken from the Global Internal Displacement Database (GIDD), made available by the Internal Displacement Monitoring Centre (IDMC). On average, 24 million people have been displaced from 2008 to 2019, with the highest number (42 million) of displacements occurring in 2010 from natural-hazard related disasters. Natural-hazard 
(a)

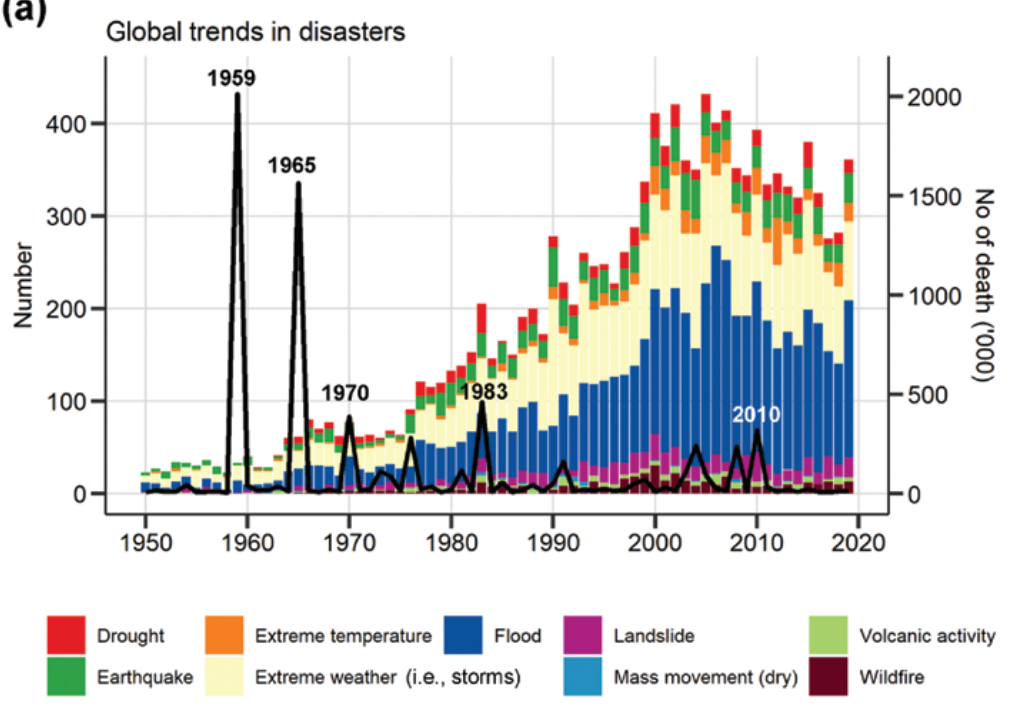

(b)

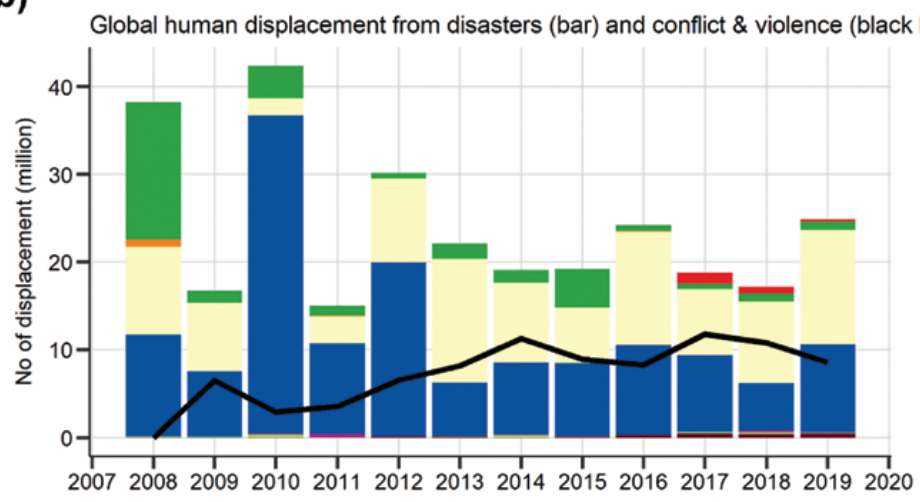

Figure 1. (a) Global trends in the number of disasters caused by various natural hazards worldwide from 1950 to 2019, along with human fatalities from those disaster events. (b) The number of human displacements globally from disasters resulting from the same set of natural hazards and conflicts and violence from 2008 to 2019. The figure legend is common for both the upper and lower panels.

displacements are principally from flooding (and coastal surges) and extreme weather. Human displacement from conflict and violence has been significantly higher in the last decade than in the previous one. In 2019, they made up a large proportion of the total displacements. For example, in coastal Bangladesh in 2020, hydro-meteorological disasters triggered 4.4 million new pre-emptive evacuations (e.g. Cyclone Amphan in May 2020). Migrants and refugee communities can be highly vulnerable to natural hazards, such as the Rohingya who fled from Myanmar to southeastern Bangladesh and face cyclones, landslides and flash-flood hazard risks (Alam et al. 2020a; 2020b). There may be no net migration for local disasters, where effective aid adequately compensates for the disaster losses (Paul 2005). But if there are no alternative mitigation 
strategies, people will migrate away from the shocks of disasters and climate change (Mbaye 2017).

\section{Sea level rise and deltaic hazards risks}

Sea-level rise is a slow-onset hazard risk that is a direct consequence of global oceanic warming and melting ice sheets. According to the Intergovernmental Panel on Climate Change (IPCC), the low-lying deltas and small islands are particularly at risk (Oppenheimer et al. 2019). Figure 2a shows global trends in sea levels from 1992 to 2020 in mm per year. These multi-hazard risk indices include tropical cyclones, flooding and landslide hazards induced by heavy precipitation. The figures illustrate the high and extremely high hazard risks of the South and Southeast Asian mega-deltas relative to other regions around the world but also the concentration of very high risk and extremely high risk areas within Bangladesh, the high sea-level rise of over 3mm/ year and high-intensity cyclones in the Bay of Bengal.

Bangladesh's $700 \mathrm{~km}$ long coastline and mega-delta are highly dynamic (Brammer 2014), driven by the ever-changing nature of sea levels. Direct consequences of sealevel rise are coastal inundation and land erosion. The presence of soil, land and water salinity due to seawater intrusion in the coastal region is a vital characteristic of the low-lying deltaic environment, including the delicate coastal ecosystems of the Sundarbans mangrove forests, home to the Bengal tiger. Slowly rising sea levels have already increased the population exposure to soil, land and water salinisation and created water-logging problems and significant health hazards in coastal Bangladesh that is home to some 35 million people. While erosion impacts livelihoods and forces people to move, affected populations never enjoy economic and social stability.

Salinity hazard risks along the coast are complex as they result from both natural processes and human activities. Naturally, salinity levels in soil and surface water are generally high (greater than five parts per thousand, ppt) in the southwest coastal area relative to the eastern coast in Bangladesh (Brammer 2014). Tidal flooding by saline water occurs in the extreme southwest (i.e. close to the Sundarbans) throughout the year. Many farmers have turned their once fertile lands to brackish-water shrimp farming because they generate higher profits than cultivating rice or other cereals. This aquaculture land-use practice since the 1970s has transformed much of the farmlands into shallow, brackish water ponds.

\section{Tropical cyclone and storm-surge hazard risks}

The northern Indian Ocean contributes to nearly 7 per cent of all global tropical cyclones (Mahala et al. 2015). The average annual number of tropical storms in the 
(a)

Sea Level Trends (mm/year)

$$
\begin{aligned}
& \square-10--5 \square-1.9--1 \square 0.1 \text { - } 1 \square 2.1 \text { - } 3 \square 4.1 \text { - } 6 \\
& \square-4.9--2 \square-0.9-0 \square 1.1-2 \square 3.1 \text { - } 4 \square 6.1 \text { - } 10
\end{aligned}
$$

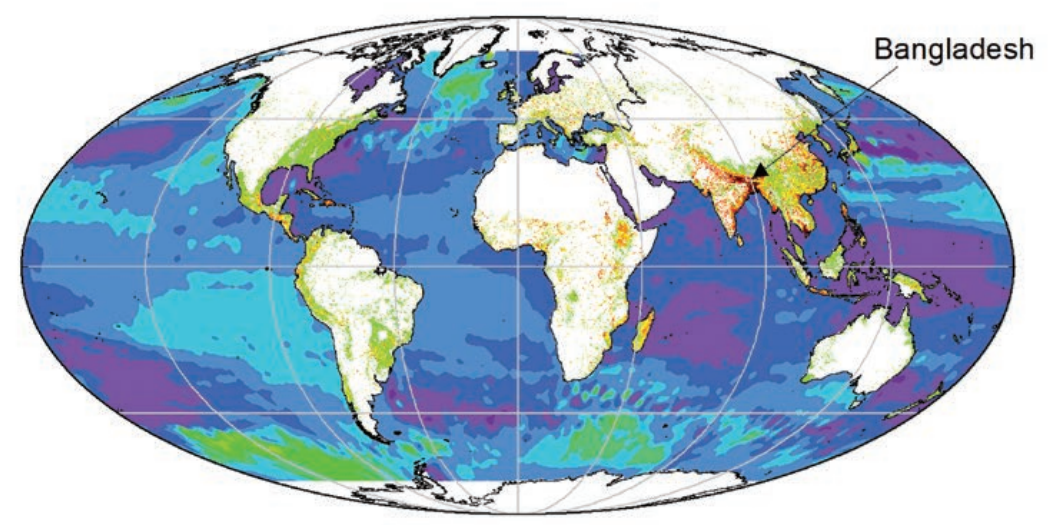

Global multihazard Risk Index

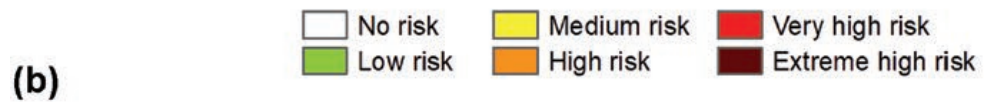

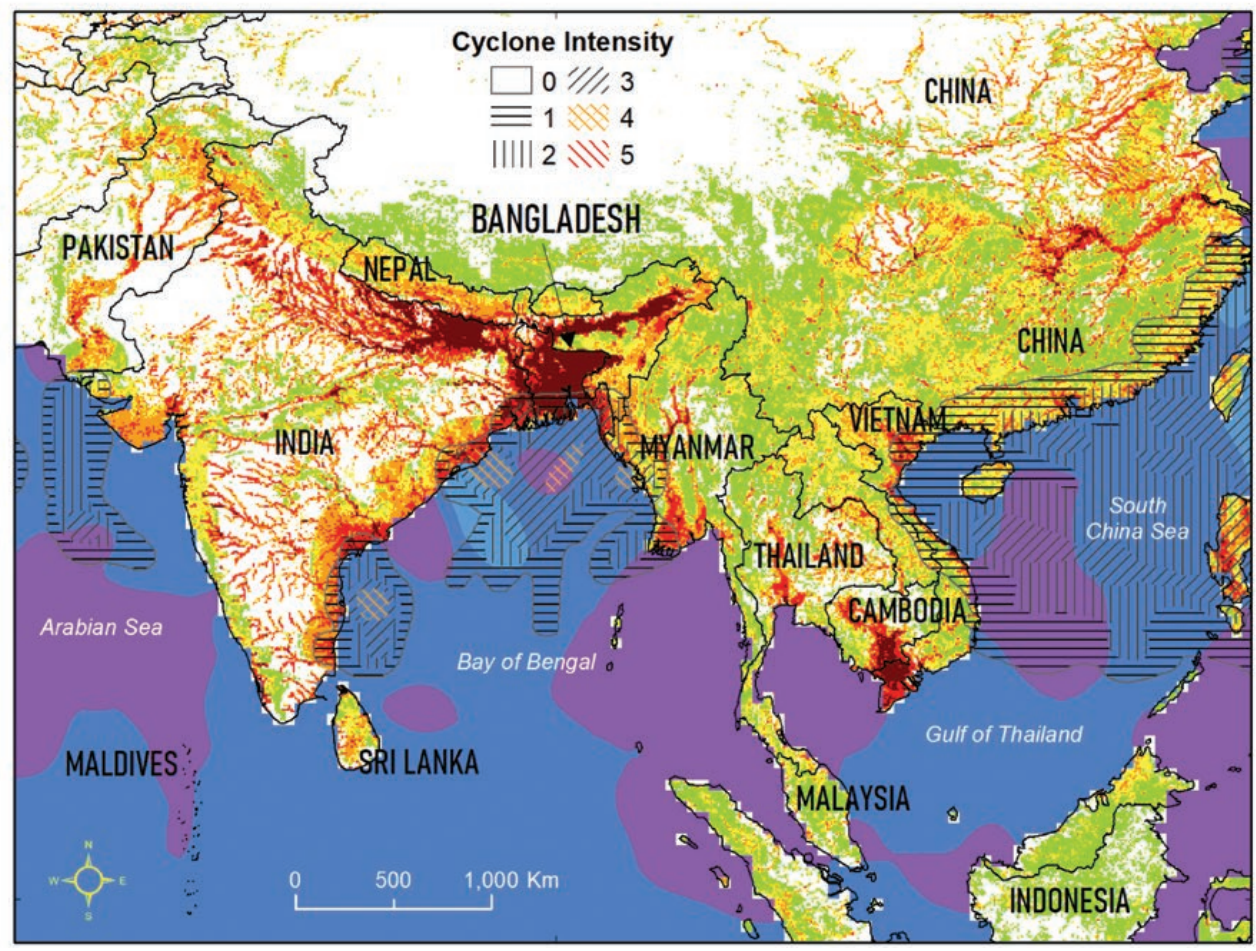

Figure 2. (a) On-ocean — global trends in sea levels from 1992 to 2020; and on-land - global multi-hazard risk indices, which include tropical cyclones, flood and landslide hazards induced by precipitation. (b) A zoomed-in map of the same features (sources: NOAA, NASA and UNEP/UNISDR). 
Bay of Bengal is about 12, out of which only five can attain cyclonic strength with a wind speed often exceeding $74 \mathrm{mi} / \mathrm{h}$ or $118 \mathrm{~km} / \mathrm{h}$ (Paul 2009). Tropical cyclones hit Bangladesh more or less every year though the intensity and severity of disasters and human impacts vary substantially. It is often strong storm surges, which the Bay of Bengal is highly exposed to (Figure 2), that cause the maximum damage. Table 1 lists some of the powerful cyclones that have hit Bangladesh since the 1970s and more recent ones. It is immediately apparent from Table 1 that the number of fatalities from the most recent cyclones is dramatically lower when compared to the historic Cyclone Bhola in 1970 and Cyclone Gorky in 1991.

Cyclone Bhola made landfall in November 1970. It was a Category 4 cyclone with an average wind speed between 131 and $155 \mathrm{mi} / \mathrm{h}(209-251 \mathrm{~km} / \mathrm{h})$ and flooded densely populated lowland plains of the Bengal delta (ESRI Storymap 2021). The loss of human lives and economic damage could have been avoided significantly if there had been sufficient preparations or evacuation plans before the event. However, just three weeks before Cyclone Bhola, a warning was given for a much smaller cyclone that hit the coast. The government (then East Pakistan) sent out evacuation orders, but the storm dissipated without causing any discernible damage. Consequently, the evacuation plans were not carried out when Cyclone Bhola was building as deploying the necessary resources were not deemed justified, which

Table 1. Major tropical cyclones in Bangladesh since the 1970s and some details on their timing and the number of deaths.

\begin{tabular}{lll}
\hline Name of cyclone & Date & No. of deaths \\
\hline Cyclone Bhola & 11 November 1970 & 300,000 \\
Cyclone Urir Char & 25 May 1985 & 11,069 \\
Cyclone 04B & 21 November 1988 & 5,708 \\
Cyclone Gorky 1991 & 19 April 1991 & 138,000 \\
Cyclone 1997 & 19 May 1997 & 155 \\
Cyclone Sidr & 15 November 2007 & 3,363 \\
Cyclone Aila & 25 May 2009 & 150 \\
Cyclone Mahasen & 16 May 2013 & 17 \\
Cyclone Roanu & 21 May 2016 & 26 \\
Cyclone Mora & 28 May 2017 & 7 \\
Cyclone Fani & 4 May 2019 & 12 \\
Cyclone Amphan & 25 May 2020 & 26 \\
\hline
\end{tabular}

Sources: The Independent (2019), www.theindependentbd.com/post/223142; ReliefWeb (2021), https://reliefweb. int/country/bgd 
ultimately left the population exposed to the oncoming disaster (ESRI Storymap 2021). The Cyclone Bhola disaster prompted the Bangladesh Cyclone Prepared Programme in 1973 and laid the foundations for the WMO's Tropical Cyclone Programme (WMO 2020).

Nearly 20 years later, in 1991, another super cyclone (Cyclone Gorky) during a lunar high tide hit the coast of Bangladesh, killing 138,000 people. The country now had a Cyclone Preparedness Programme, cyclone early-warning system and cyclone shelters. Yet, the number of fatalities and economic damage from the cyclone was catastrophic. Khalil (1993) examined the cyclone disaster and concluded that the strong wind (recorded up to $225 \mathrm{~km} / \mathrm{h}$ ) and high tide favoured the exceptionally high (up to $9 \mathrm{~m}$ ) storm surges associated with the cyclone and that the storm surges almost exclusively caused the human casualties. In addition, the study found that a majority of the residents did not want to evacuate even though they received warnings about the cyclone. But early warning information about the cyclone and the floods was transmitted by men to men in public spaces, rarely reaching women directly and in part explaining why five times more women than men died (Ikeda 1995). The consequences can be significant when warning systems do not consider gender differences, as the 1991 Bangladesh Cyclone demonstrated.

In contrast, Cyclone Sidr in 2007, despite being a superstorm, took fewer lives $(3,363)$, although it caused substantial economic losses totalling nearly USD 1.7 billion (Paul 2009) because of successful warning and evacuation. The storm surge associated with Cyclone Aila in 2009 displaced almost 1 million people, destroyed 175,000 homes and rice farmland (Higgins et al. 2014) but took much fewer lives (150). Cyclone Amphan, which made landfall on 20 May 2020, displaced 2.5 million people (WMO 2021), inundated over 400,000 hectares of land and damaged rural households but claimed few lives (26). Provision of a timely cyclone forecast, an effective early warning and successful evacuation of coastal residents are all factors behind the reduction in the death toll (Kelman et al. 2018). However, cyclone shelters are not available to the over one million Rohingya refugees currently living in southeastern Bangladesh. The Rohingya mostly live under bamboo and polythene sheeting temporary structures, which are highly vulnerable to cyclone hazards (Zaman et al. 2020).

\section{Rainfall-triggered flood and landslide hazard risks}

Bangladesh has the world's largest river network with a total number of nearly 700 rivers. The major river floodplains and regional depressions are the most flood-prone areas, and floods affect 20-25 per cent of the country every year. These are shown in Figure 3 for rapid-onset hydro-meteorological hazard risks: flash floods, river floods, 
tidal surges and river erosion, and graded for the level of risk. The southern and northern hilly terrains and regional depressions are prone to flash floods in the early part of the monsoon season.

Catastrophic flooding occurred in Bangladesh in 1974, 1987, 1988, 1998, 2004, 2007, 2017 and 2020. Figure 4 shows the percentage of flood-affected areas from 1954 to 2020. Data is sourced from the Bangladesh Flood Forecasting and Warning Centre (FFWC; www.ffwc.gov.bd/). The flood-affected area in Bangladesh is highly

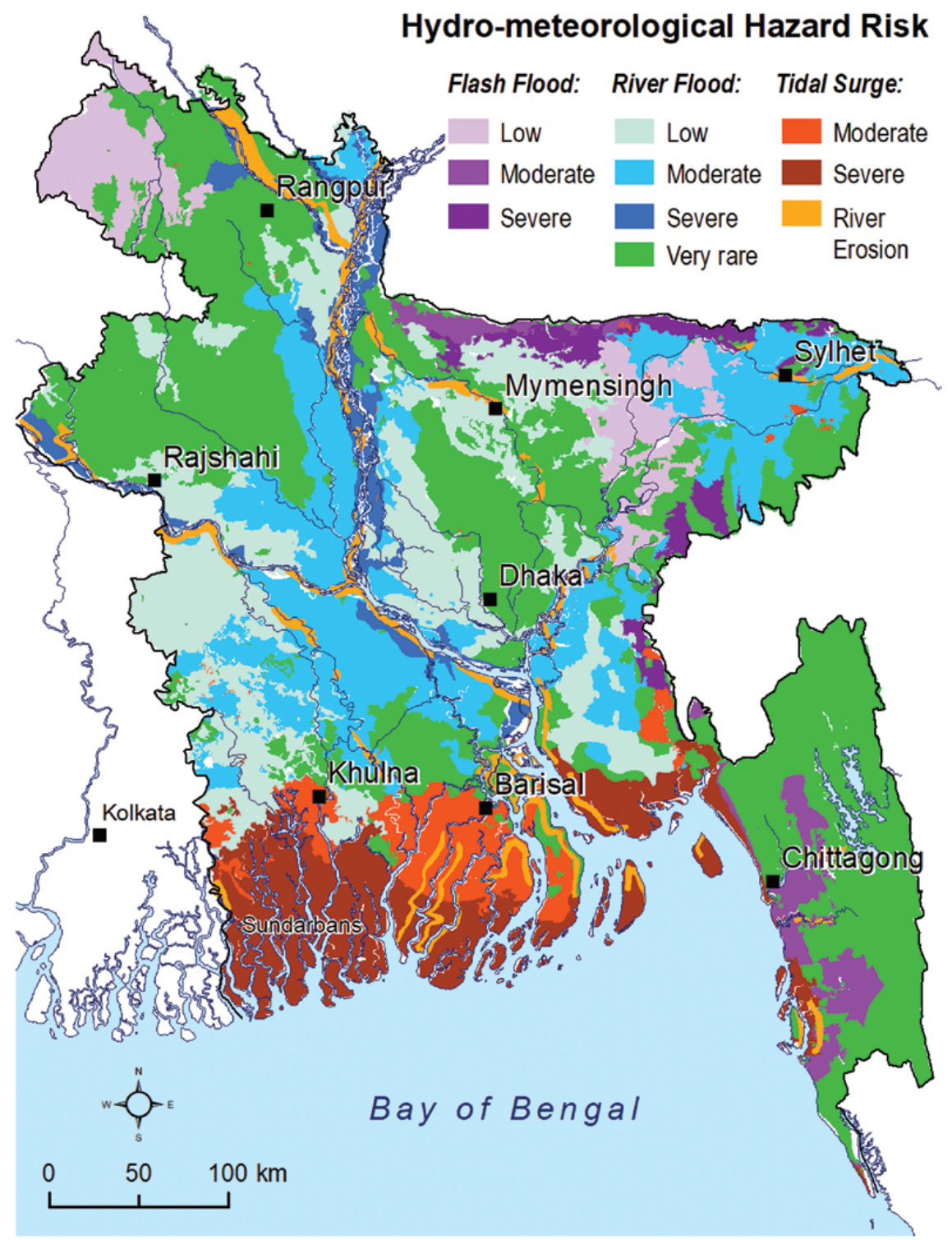

Figure 3. National-scale map showing rapid-onset groups of hydro-meteorological (e.g. flash floods, river floods, tidal surges, and river erosion) hazard risks. 


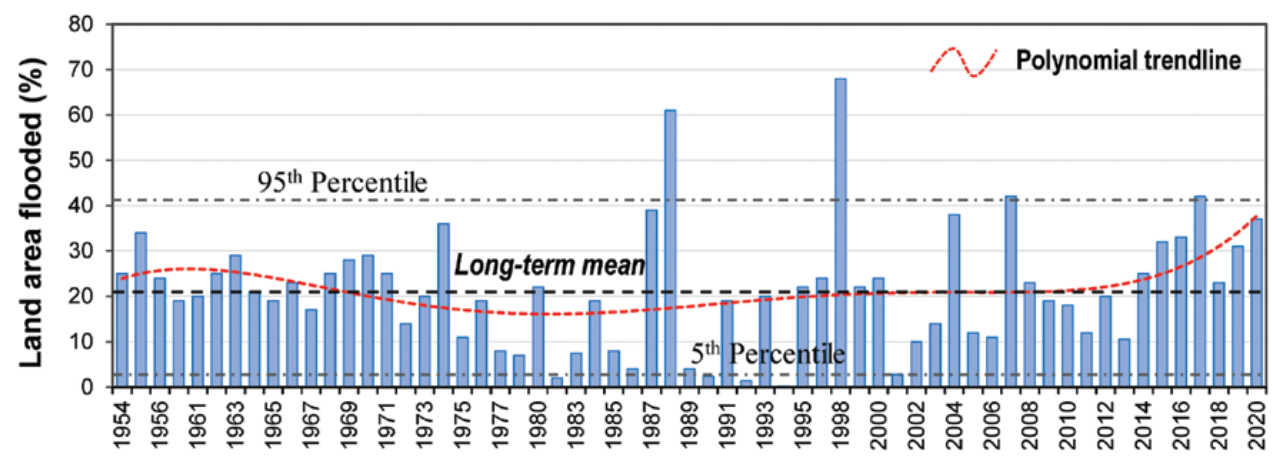

Figure 4. Flood-affected area in Bangladesh (total area: 147,570 $\mathrm{km}^{2}$ ) for the period of 1954 to 2020 . The long-term (1954-2020) polynomial trendline is plotted.

variable around a long-term mean value of 20 per cent of the total land area. Except for 1988 and 1998, the flooded area is generally below 40 per cent of the land area. The long-term (1954-2020) polynomial trend suggests that there is an upward trend. Some 1,050 people died, 30 million people were affected, and 25 million people were made homeless in the 1998 catastrophic flood disaster in Bangladesh (statistics from ReliefWeb; https://reliefweb.int/). A total of 251 people died in the most recent flood in 2020 that affected nearly 37 per cent of the country in two separate waves that stretched the flood season well into August.

Related to flooding is river erosion which is a flood-related hazard risk. It is often river erosion during the monsoon season that triggers disaster in floodplain communities on short timescales. River erosion is commonly observed along the banks of the major river channels in the country (Figure 3a). For example, statistics show that nearly $57 \mathrm{~km}^{2}$ of land was lost along the right bank of the River Ganges, whereas around $59 \mathrm{~km}^{2}$ was gained along the left bank during the 1973-2011 period (Dewan et al. 2017). People living along the riverbanks are part of the most vulnerable communities in the River Ganges floodplain, and their fate is primarily regulated by the dynamic nature of the river (Bhuiyan et al. 2017). Over the longer term, river erosion triggers human displacement and internal migration.

At present, landslides constitute a significant threat to the hilly communities in Bangladesh. Landslides are particularly prevalent in the southeastern Chittagong Hill Districts during the monsoon season. The primary driver for landslides is extreme rainfall events (i.e. greater than $200 \mathrm{~mm}$ in five consecutive days). But landslide disasters result from complex socio-economic vulnerabilities and physical susceptibility to landslides and hazards in the region. The root causes of landslide vulnerability in the region were identified as hill cutting and deforestation for housing development, Rohingya refugee influx, lack of institutional transparency, dysfunctional urban planning measures, settler Bengali versus indigenous tribal community conflicts and absence of an effective landslide early warning system (Ahmed 2021b). 


\section{Reduction of disaster risks in Bangladesh}

The population of Bangladesh has increased steadily over the decades-although its current annual growth rate has dropped to 1 per cent (United Nations, Population Division). Since 1970, the year of Cyclone Bhola, its population has increased from 64 million to 80 million in 1980 , to 128 million in 2000, to the current population of 166 million; while population density has increased from 493 to 612 , to 981 to 1,265 people per $\mathrm{km}^{2}$ respectively. So, the exposure to hazards risks could have increased severely over this time. But, as shown above, the number of deaths from hazard events has fallen equally dramatically over that period. Over this time, the average life expectancy has noticeably increased from 47 years in 1971 to 75 years in 2019 for women and from 46 years to 71 years for men (https://data.worldbank.org/). At the same time, gross domestic product (GDP) has increased from USD 4.3 to 324.2 billion at constant prices. GDP per capita on a purchasing power basis has grown from USD 1,518 to 4,181 . Significant progress has also been made in poverty reduction: the poverty rate dropped to 20.5 per cent in 2019 from 23 per cent in 2016 and 49 per cent in 2000. Poverty is considered a key element in determining vulnerability to climate change (Hallegatte et al. 2015; Jones et al. 2021) because the climate crisis is regarded as a vulnerability multiplier.

Two economic sectors, in particular, contributed to this spectacular performance: Bangladesh's textile industry, accounting for 83 per cent of its total export revenues of $\$ 30$ billion; and the agricultural sector, which employs over 40 per cent of the workforce, which went through a 'Green Revolution'. Women's employment in the readymade garment sector (about 60 per cent of garment workers are female) has played a significant role in supporting their livelihoods and empowering them (ILO 2020), even if it has increased women's vulnerability when factories are poorly constructed and maintained.

In the drought-prone northwestern Barind tract region, millions of people died in devastating famines in the past that were linked directly to disasters and indirectly to lack of entitlement and weak governance (Davis 2017). The famine of 1974 was one of the worst humanitarian crises that the country had faced and cost at least 26,000 human lives due to starvation (though the unofficial figures range from 80,000 to 100,000 to even over a million deaths from hunger and malnutrition) (Sen 1981). As a young nation, addressing food shortages and long-term security was a monumental task. However, Bangladesh has made remarkable progress in the four dimensions of food security: food availability, food access, food utilisation and food stability (Dev \& Kabir 2020). Bangladesh has reduced death rates to zero in the Barind tract region, and poverty reduction has been significant. The farmers now produce diverse crops three to four times a year because of access to irrigation water and agricultural innovation, and they have alternative livelihood opportunities (Ahmed et al. 2019). 
There were two main obstacles in addressing food security: (1) land ownership and (2) irrigation water supply for agriculture. Inequality and land-ownership problems date back to the British colonial period that introduced the 'Zamindari' system in 1793, ultimately abolished in 1946. The Zamindari system led to absentee landlords of the urban areas taking over the control of land in rural areas and farmers, in particular, becoming almost landless (Ali 2005). Today, land ownership and disputes still exist, but millions of smallholder farmers have collectively contributed to the journey of food-secure Bangladesh. The second critical issue was irrigation water supply, as the country was highly dependent on rainfall before the 1970s. During the Green Revolution, Bangladesh and other South and Southeast Asian countries transformed agricultural production (Hazell 2009), livelihoods and nutrition for their people. Government interventions were essential for ensuring that smallholder farmers were included in the revolution and not left behind. The fuel that drove the Green Revolution in Bangladesh was groundwater. This hidden resource is resilient to drought and climate change compared to highly seasonal and unpredictable surface water. Today, Bangladesh produces rice in approximately 40 per cent of its irrigated lands compared to 12 per cent back in the 1970s; today, nearly 80 per cent of all irrigation water supply comes from groundwater (Shamsudduha et al. 2020).

Since the early 1970s, Bangladesh progressively instituted disaster risk reduction (DRR) plans and legal frameworks, climate change strategies, enhanced institutional capacity, supported vulnerable communities, invested in climate-resilient infrastructure, and developed innovative digital technologies (Kazi 2020). To address cyclone hazard risks, the Bangladesh government invested in cyclone preparedness, communitybased early warning systems, hydro-meteorological DRR initiatives, and adaptive delta management, combined with structural interventions. These efforts ultimately saved human lives, reduced economic losses and protected development gains (Kazi 2020). There are two crucial areas where Bangladesh has transformed cyclone and extreme weather-related exposure in the country: (1) climate-resilient infrastructure such as the construction of cyclone shelters and coastal polder embankments; and (2) development of cyclone early warning systems and evacuation plans backed by DRR education and training. In the 1970s, the country had only 42 cyclone shelters, whereas now, over 12,000 functional cyclone shelters can accommodate nearly 5 million people. However, people are still taking a 'wait-and-see' approach mainly due to the fear of losing properties (Hadi et al. 2021). Compared to the pre-independence state (1971), the country has invested immensely in constructing thousands of kilometres of flood-protective embankments (also known as polders) to protect the coastal population of almost 35 million who live with the high risk of sea-level rise, tidal inundation, storm surges and saline-water intrusion. However, whilst polders have protected against storm surges and fluvial-tidal events of moderate severity, they have exacerbated more frequent flooding from heavy rainfall and promoted potential 
flooding impacts during the most extreme storm surges (Adnan et al. 2019). These are consistently impacting livelihoods and critical infrastructure (Kelman \& Ahmed 2020). Local people, non-governmental organisation (NGOs) and public authorities are working together to implement the indigenous tidal river management schemes and nature-based solutions to adapt to the changing climate and upstream reduction of freshwater discharge. Other initiatives include installing flood-resilient hand tube-wells, raising latrines, providing community awareness training, improving early warnings and evacuation systems, training volunteers, and promoting alternative livelihood opportunities. This is illustrated in Figure 5, where a range of livelihood options in rural, coastal regions in Bangladesh are shown, including a backyard plantation, a small village shop, an in-house clothing and tailoring business, and cattle rearing (Ahmed et al. 2016).

The COVID-19 pandemic has revealed fragility across high and low-income countries worldwide and highlighted how vulnerable and ill-prepared we are in tackling the global crisis. Bangladesh is not immune to the COVID-19 problem, which has caused setbacks in gains towards sustainable development. Significantly, a pandemic will also impact the response to a disaster such as a cyclone. For instance, cyclone shelters could become vehicles for the transmission of infectious diseases. While on the other

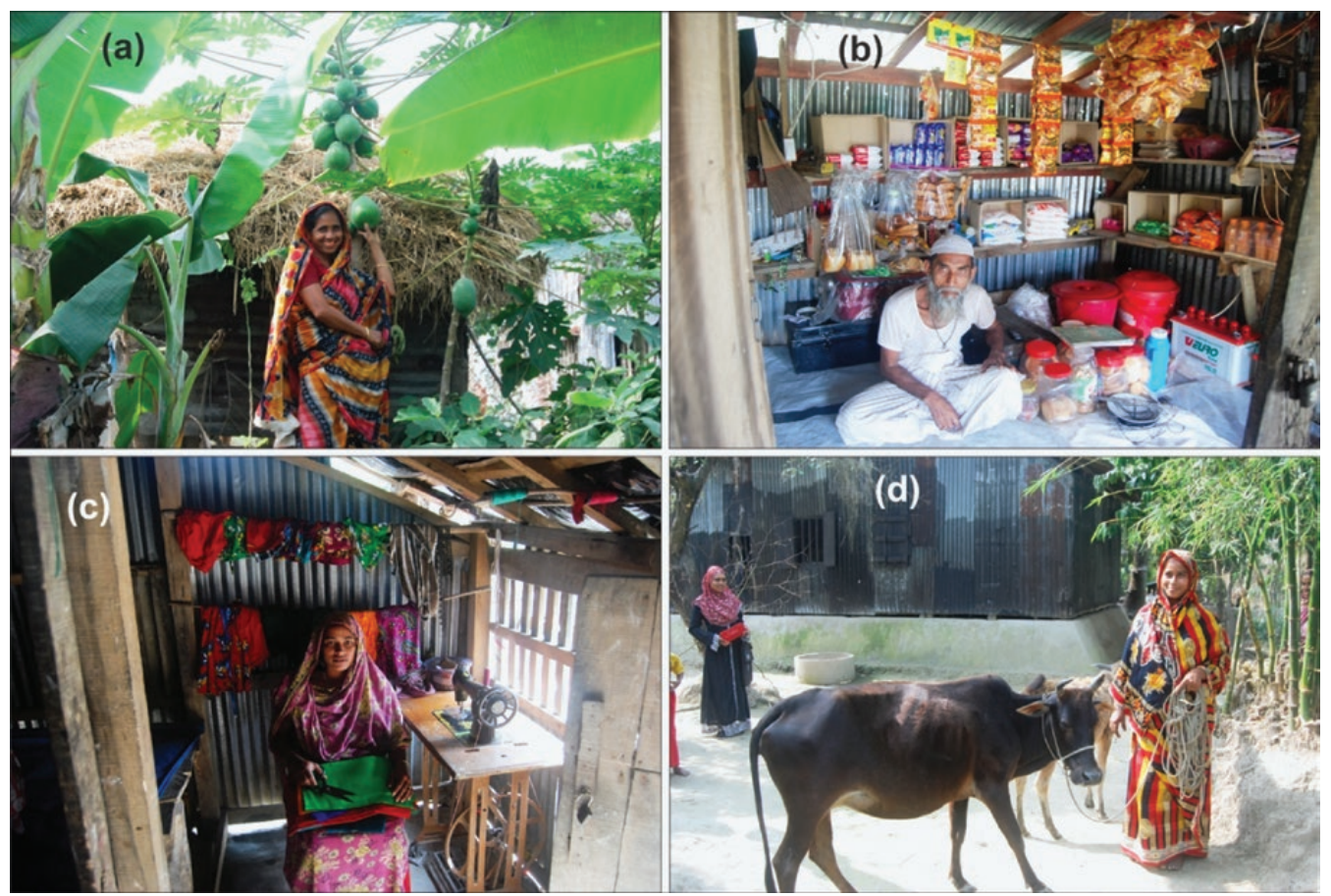

Figure 5. A range of livelihood options in the rural, coastal region in Bangladesh: (a) backyard plantation, (b) small village shop, (c) in-house clothing and tailoring business, and (d) cattle rearing (source: Ahmed et al. 2016). 
hand, hospitalisations and demands on health care services could impact the disaster response.

\section{Climate change, disasters and human displacement}

Bangladesh is making significant progress towards reaching the UN Sustainable Development Goals (Munir 2019) and is performing well in poverty reduction, gender equality and annual GDP growth. The fact that Bangladesh is rapidly developing and has one of the highest growth rates in the world (3.79 per cent in 2020) (IMF 2021) and poverty rates which have halved in 20 years (to 20.5 per cent in 2019) (World Bank 2021) means there are natural grounds for optimism. Bangladesh is on track to achieve the first three SDGs to end poverty, hunger and improve public health. But human-induced climate change could reverse these spectacular development achievements. Overall, the combined effects of climate change could be responsible for a loss of 1-2 per cent of GDP per year in Bangladesh (GED 2018). It took centuries for the local communities and the country as a whole to reach this level. Moreover, there is a strong correlation between poverty and intensity of natural hazard exposure; 67 per cent of the top high-risk districts have poverty rates higher than the Bangladesh national average (GED 2018). Consequently, the DRR advances are also at risk.

According to the Bangladesh Delta Plan 2100 (GED 2018), it is anticipated that by 2050 there could be an increase in the intensity of tropical cyclones (i.e. a 10-year return period cyclone will be more intense and cover 17 per cent more area), and an increase in tidal storm surges and coastal floods with an inundation depth of 14-69 per cent higher than the present level. These intensified coastal hazards would accelerate human migration to urban areas within the country and beyond in the coming decades. Dasgupta et al. (2010) analysed the vulnerability of Bangladesh to cyclones in a changing climate, the potential damage and adaptation cost. They identified the polders, coastal populations, settlements, infrastructure and economic activity at risk of inundation. A $27 \mathrm{~mm}$ sea-level rise, which has since occurred, and 10 per cent intensification of wind speed, would increase the exposed zone by 69 per cent, and an estimated 59 of the 123 polders would be overtopped during storm surges. Another 5,500 cyclone shelters would be needed. The primary driver for landslides is extreme rainfall events (i.e. greater than $200 \mathrm{~mm}$ in five consecutive days) that are becoming more frequent due to climate change (Kirschbaum et al. 2020). Therefore, substantial strengthening of DRR infrastructure and early warning systems will have to be invested in continuously.

The imminent threats to food security are still present as reduced rainfall because of climate change, depletion of groundwater, and water management in the upstream countries can cause severe agricultural droughts and water scarcity (GED 2018). 
Both meteorological and agricultural drought are observed from time to time as low precipitation leads to soil moisture deficit and, thus, limited crop growth in the drought-prone areas (Prodhan et al. 2020). Due to extreme seasonality in Bangladesh, drought-like conditions are observed, particularly in the northwestern, north-central and southwestern regions. Climatological hazard risk areas are shown in Figure 6, where slow-onset groups of climatological hazard risks (particularly drought) and climate-driven but anthropogenic hazard risks (e.g. the depletion of groundwater storage) are well-mapped. The impacts of climate change could extensively reduce rice and wheat production by 17 per cent and 61 per cent, respectively. An increasing proportion of coastal Bangladesh could experience seasonal to permanent inundation, and the increase in saltwater intrusion can negatively affect agriculture-based livelihoods and ecosystems. It is anticipated that by 2050 there may be an increase in soil salinity (18 to 24 per cent) in the entre coastal region (GED 2018).

Currently, nearly 98 per cent of the population get their drinking water from groundwater as the surface water is highly polluted. Some waterborne (e.g. diarrhoea, cholera) and vector-borne diseases (e.g. dengue, chikungunya, malaria) are likely to be intensified with climate change. Groundwater provides almost 80 per cent of all irrigation water supplies that are critically needed to produce crops, primarily the dry-season 'Boro' rice, without which Bangladesh would not have been able to achieve near self-sufficiency in food grains (Shamsudduha et al. 2020). This phenomenon is also true for other nations in South and Southeast Asia (e.g. India), where irrigated agriculture through the 'Green Revolution' (Hazell 2009) since the 1960s has helped countries achieve near self-sufficiency in food grains.

There is a growing concern of substantial human displacement and migration, both within the country and beyond the border, as a result of increased climate-induced environmental hazards and disasters (Hauer et al. 2020). The IPCC reported a strong correlation between global temperature rise and out-migration due to extreme poverty from agriculture-dependent communities (Hoegh-Guldberg et al. 2018). Nearly 1,900 natural hazard-induced disasters triggered around 25 million new internal displacements across 140 countries in 2019 alone. The number is three times higher than conflict and violence-related displacements, and of which approximately 24 million people were displaced solely due to extreme weather-related disasters globally (IDMC 2020). Each year since 2008, disasters forcefully displaced an average of 25 million people, and 97 per cent of them were related to climate-related disasters. Most of them originated from the least developed countries (IDMC 2020) because communities in the Global South are often less prepared due to pre-existing social inequalities, lack of access to advanced technologies and limited ability to adapt to the changing climate. That might trigger displacement and human migration through sustained economic losses and environmental degradation. 


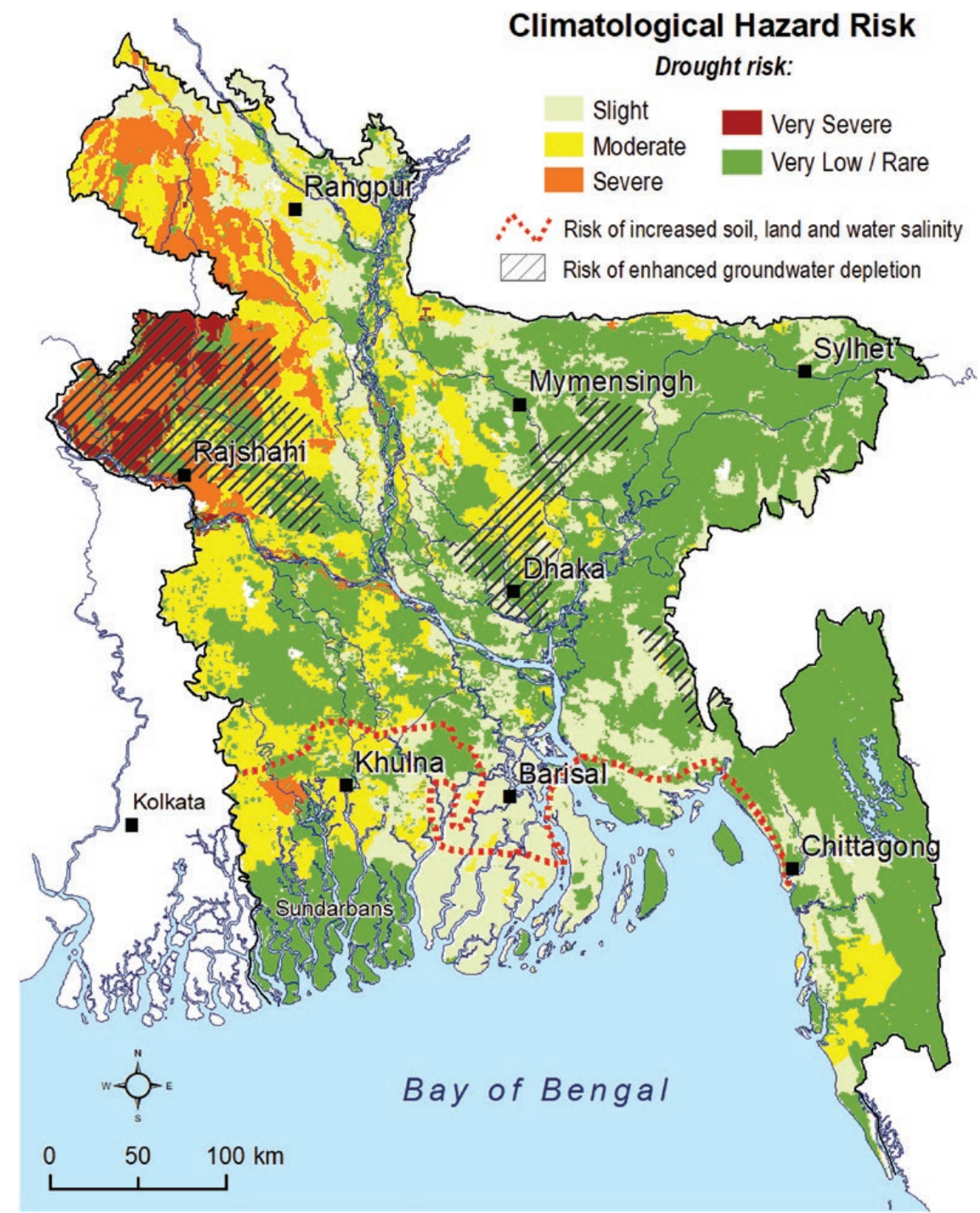

Figure 6. National-scale map of slow-onset groups of climatological (e.g. drought, soil, land and water salinisation), and climate-driven but anthropogenic (e.g. depletion of groundwater storage) hazard risks in Bangladesh.

Bangladesh has developed adaptation strategies to minimise forced displacement. However, situations arise when people need to move (Chen \& Mueller 2018). For example, in 2020, the monsoon floods affected 5.4 million people, their livelihoods and their homes, resulting in homelessness and prolonged displacement for thousands of people (UNDRR 2020). Between 2001 and 2011, we calculated around 5.6 million environmental migrants in Bangladesh, of whom 2 million were climate migrants (Ahmed 2021a). These data are presented in Figure 7. The authors produced the figure in a new analysis of 337,000 national-level household survey data from the 


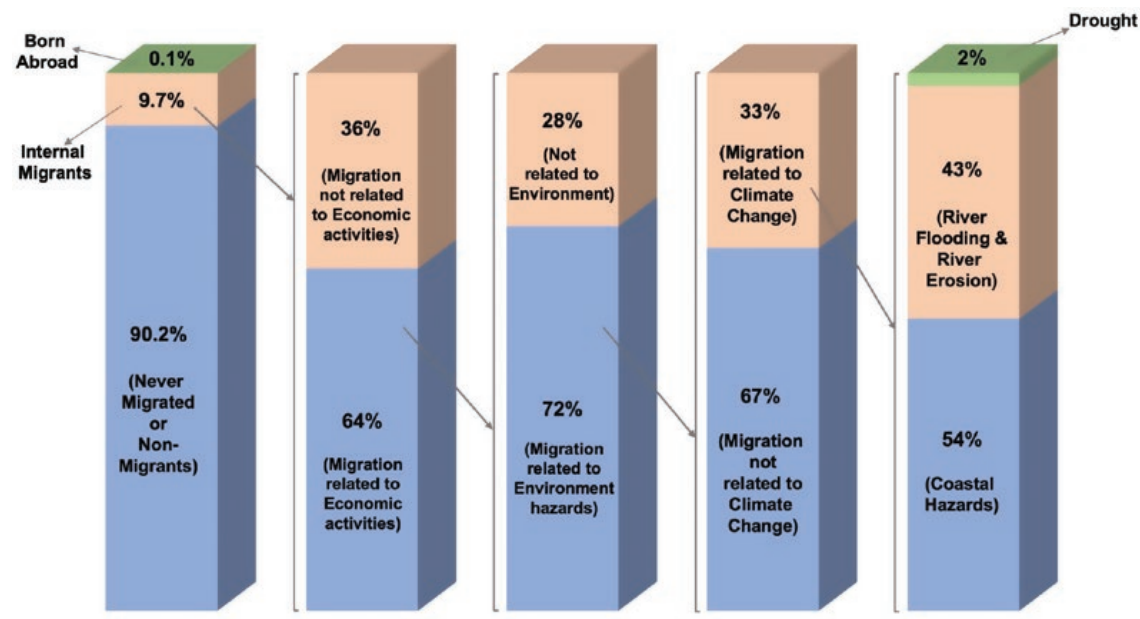

Figure 7. The distribution of economic, environmental and climate migrants in Bangladesh.

Bangladesh Bureau of Statistics (2001-11). It shows the distribution of economic, environmental, and climate migrants in Bangladesh. We found that only around 9.7 per cent of the population migrated internally, of which 64 per cent were economic migrants. Of the economic migrants, 72 per cent were environmental migrants, of whom climate change forced 33 per cent of the migrants primarily (Figure 7). The World Bank estimates the number could reach up to 13 million by 2050 (Rigaud et al. 2018). As a whole, climate change is aggravating other drivers of human displacement - disruption to livelihoods, agricultural activities, food insecurity, intensifying extreme poverty, freshwater scarcity, and enhanced vulnerabilities related to governance and socioeconomic factors. As a result, agriculture-dependent marginalised people are being forced to relocate to large urban areas to seek a better life. Still, they often find themselves getting trapped in poverty and insecurity (Ahmed 2021a).

\section{Summary and recommendations}

In this case study, we reviewed both rapid and slow-onset natural hazard risks in Bangladesh which are often cited as the most vulnerable country to climate change. Here, we analysed a range of hazard risks and disaster events and discussed how the country has developed economically and socially over the last 50 years and has been building its resilience to natural hazards and associated disasters. Today, fewer people die from natural-hazard related disasters in the country compared to the 1970s. It is a remarkable achievement when considering the increase in population and greater physical exposure to disaster risks. 
With significant economic growth over the last 50 years, reduction in poverty, self-sufficiency in food production, infrastructure development, digital and mobile technologies (e.g. access to mobile telephones, high-speed internet) and collective social changes, the country is now much more resilient to disasters. Development of disaster risk reduction (DRR) infrastructure (e.g. coastal embankments, cyclone shelters) and early warning systems, combining technology and social education, have been crucial. These societal changes and development initiatives by the government, private sector and NGOs systematically introduce resilience to natural and anthropogenic changes in Bangladesh.

Natural hazards and associated disasters intensify due to climate change, unsustainable development, rapid urbanisation and population growth, particularly in the Global South, including Bangladesh. The COVID-19 pandemic has unveiled both strengths and weaknesses in our societies. In this highly polarised and unequal world, climate mitigation alone cannot protect millions of vulnerable people in Bangladesh who are likely to face catastrophic disasters through intensified natural hazard events. Countries like Bangladesh should focus on adaptation, technological solutions, globalscale collaboration, ongoing social transformation and enhancing their resilience to the emerging climate crisis.

Disaster management plans need to be revised dynamically to assess how to adapt them to respond during a pandemic, considering the potential for infectious disease transmission. These plans need to address specifically the need to reduce the vulnerability of refugee, internally displaced and migrant communities whose numbers are likely to increase. Furthermore, strategies need to specifically address gender responses to hazard events and warnings. There will need to be substantial and continuing investments in early warning systems and DRR infrastructure.

\section{Acknowledgements}

We kindly acknowledge the support from the British Academy (award reference no. SDP2\100094) and the Royal Society (award reference no. CHL\R1\180288) research grants received under the UK Government's Global Challenges Research Fund (GCRF) programme. Professor Maureen Fordham provided constructive criticism.

\section{References}

Adnan, M.S.G., Haque, A. \& Hall, J.W. (2019), 'Have Coastal Embankments Reduced Flooding in Bangladesh?', Science Total Environment, 682: 405-16.

Ahmed, B. (2021a), 'Climate Migrants in Bangladesh: A Journey towards Uncertainty!', presented at the 2020 Global Shifts Colloquium: Seeking Refuge in the Climate Emergency September 
2020, Perry World House, University of Pennsylvania, USA. https://drive.google.com/ file/d/1b5Jec27FvAXhXqniOBl-f0CTvhddyGwD/view?usp=sharing

Ahmed, B. (2021b), 'The Root Causes of Landslide Vulnerability in Bangladesh', Landslides, 8: 1707-20. https://doi.org/10.1007/s10346-020-01606-0

Ahmed, B., Kelman, I., Fehr, H.K. \& Saha, M. (2016), 'Community Resilience to Cyclone Disasters in Coastal Bangladesh', Sustainability, 8: 805. https://doi.org/10.3390/su8080805

Ahmed, B., Kelman, I., Kamruzzaman, M., Mohiuddin, H., Rahman, M.M., Das, A., Fordham, M. \& Shamsudduha, M. (2019), 'Indigenous People's Responses to Drought in Northwest Bangladesh', Environmental Development, 29: 55-66. https://doi.org/10.1016/j.envdev.2018.11.004

Alam, A., Ahmed, B. \& Sammonds, P. (2020a), 'Flash Flood Susceptibility Assessment Using the Parameters of Drainage Basin Morphometry in SE Bangladesh', Quaternary International, 5756: 295-307. https://doi.org/10.1016/j.quaint.2020.04.047

Alam, A., Sammonds, P. \& Ahmed, B. (2020b), 'Cyclone Risk Assessment of the Cox's Bazar District and Rohingya Refugee Camps in Southeast Bangladesh', Science of The Total Environment, 135360. https://doi.org/10.1016/j.scitotenv.2019.135360

Alexander, D.E. (2018), Natural Disasters (London, Routledge). https://doi.org/10.4324/9781315859149

Ali, A. (2005), 'Livelihood and Food Security in Rural Bangladesh: The Role of Social Capital', Ph.D. thesis (Wageningen, Netherlands, Wageningen University).

Bahadur, A. \& Simonet, C. (2015), 'Disaster mortality', Briefing (Target 1). Overseas Development Institute (ODI). https://odi.org/en/publications/disaster-mortality/

Bhuiyan, M.A.H., Islam, S.M.D.U. \& Azam, G. (2017), 'Exploring Impacts and Livelihood Vulnerability of Riverbank Erosion Hazard among Rural Household along the River Padma of Bangladesh', Environmental Systems Research, 6. https://doi.org/10.1186/s40068-017-0102-9

Brammer, H. (2014), 'Bangladesh's Dynamic Coastal Regions and Sea-level Rise', Climate Risk Management, 1: 51-62. https://doi.org/10.1016/j.crm.2013.10.001

CAT (2021), Climate Action Tracker, Climate Analytics and NewClimate Institute. https://climateactiontracker.org/documents/871/CAT_2021-09_Briefing_GlobalUpdate.pdf

Chen, J. \& Mueller, V. (2018), 'Coastal Climate Change, Soil Salinity and Human Migration in Bangladesh', Nature Climate Change, 8: 981-5. https://doi.org/10.1038/s41558-018-0313-8

COP26 (2021), UN Climate Change Conference, United Nations Framework Convention on Climate. https://ukcop26.org

Dasgupta, S., Huq, M., Khan, Z.H., Ahmed, M.M.Z., Mukherjee, N., Khan, M.F. \& Pandey, K. (2010) 'Vulnerability of Bangladesh to Cyclones in a Changing Climate: Potential Damages and Adaptation Cost', The World Bank Development Research Group Environment and Energy Team, April 2010.

Davis, I. \& Alexander, D. (2015), Recovery from Disaster (Oxford, Routledge).

Davis, M. (2017), Late Victorian Holocausts: El Niño Famines and the Making of the Third World (London, Verso Books).

Dev, D.S. \& Kabir, K.H. (2020), 'COVID-19 and Food Security in Bangladesh: A Chance to Look Back at What Is Done and What Can be Done', Journal of Agriculture, Food Systems, and Community Development, 9: 143-5. https://doi.org/10.5304/jafscd.2020.094.008

Dewan, A., Corner, R., Saleem, A., Rahman, M.M., Haider, M.R., Rahman, M.M. \& Sarker, M.H. (2017), 'Assessing Channel Changes of the Ganges-Padma River System in Bangladesh using Landsat and Hydrological Data', Geomorphology, 276: 257-79.

Eckstein, D., Künzel, V. \& Schäfer, L. (2021), Global Climate Risk Index 2021 (Bonn, Germany, Germanwatch). www.germanwatch.org/en/cri

ESRI Storymap (2021), 'Bhola Cyclone in 1970'. www.arcgis.com/apps/MapJournal/index. html?appid=f3cdea1974eb48d584e1ca8c76bc6a92

GED (2018), Bangladesh Delta Plan 2100: Bangladesh in the 21st Century (Abridged Version) (Dhaka, General Economics Division (GED), Bangladesh Planning Commission). 
Hadi, T., Islam, M.S., Denise, R. \& Fakhruddin, B. (2021) 'Seeking Shelter: The Factors that Influence Refuge since Cyclone Gorky in the Coastal Area of Bangladesh', Progress in Disaster Science, $11,100179$.

Hallegatte, S., Bangalore, M., Bonzanigo, L., Fay, M., Kane, T., Narloch, U., Rozenberg, J., Treguer, D. \& Vogt-Schilb, A. (2015), Shock Waves: Managing the Impacts of Climate Change on Poverty (Washington, DC, World Bank). https://doi.org/10.1596/978-1-4648-0673-5

Hannah, R. \& Max, R. (2014), Natural Disasters (Oxford, Our World In Data). https://ourworldindata. org/natural-disasters

Hauer, M.E., Fussell, E., Mueller, V., Burkett, M., Call, M., Abel, K., McLeman, R. \& Wrathall, D. (2020), 'Sea-level Rise and Human Migration', Nature Reviews Earth \& Environment, 1: 28-39. https://doi.org/10.1038/s43017-019-0002-9

Hazell, P.B.R. (2009), 2020 Vision: The Asian Green Revolution (The International Food Policy Research Institute (IFPRI)). www.ifpri.org/publication/asian-green-revolution

HCTT (2021) HCTT Nexus Strategy (2021-2025): Humanitarian-Development Collaboration for Climate-Related Disasters in Bangladesh, United Nation Bangladesh in Collaboration with the Ministry of Disaster Management and Relief. www.humanitarianresponse.info/en/operations/ bangladesh/document/draft-hctt-nexus-strategy-2021-2025-humanitarian-development

Higgins, S.A., Overeem, I., Steckler, M.S., Syvitski, J.P.M., Seeber, L. \& Akhter, S.H. (2014), 'InSAR Measurements of Compaction and Subsidence in the Ganges-Brahmaputra Delta, Bangladesh', Journal Geophysical Research: Earth Surface, 119: 1768-81.

Hoegh-Guldberg, O., Jacob, D., Taylor, M., Bindi, M., Brown, S., Camilloni, I., Diedhiou, A., Djalante, R., Ebi, K.L., Engelbrecht, F., Guiot, J., Hijioka, Y., Mehrotra, S., Payne, A., Seneviratne, S.I., Thomas, A., Warren, R. \& Zhou, G. (2018), Impacts of $1.5^{\circ} \mathrm{C}$ Global Warming on Natural and Human Systems. www.ipcc.ch/sr15/chapter/chapter-3/

IDMC (2020), GRID 2020: Global Report on Internal Displacement (Geneva, The Internal Displacement Monitoring Centre). www.internal-displacement.org/global-report/grid2020/

Ikeda, K. (1995) 'Gender Differences in Human Loss and Vulnerability in Natural Disasters: A Case Study from Bangladesh', Indian Journal of Gender Studies, 2, 2. https://doi. org/10.1177/097152159500200202

ILO (2020). Understanding the Gender Composition and Experience of Ready-Made Garment (RMG) Workers in Bangladesh (International Labour Organization (ILO) Bangladesh and UN Women Bangladesh). www.ilo.org/wcmsp5/groups/public/---asia/---ro-bangkok/---ilo-dhaka/documents/ publication/wcms_754669.pdf

IMF (2021), World Economic Outlook 2021 (International Monetary Fund). www.imf.org/en/ Publications/WEO/Issues/2021/03/23/world-economic-outlook-april-2021

Jones, L., Halstead, F., Parsons, K.J., Le, H., Bui, L.T.H., Hackney, C.R. \& Parsons, D.R. (2021), '2020-Vision: Understanding Climate (In)Action through the Emotional Lens of Loss', Journal of the British Academy, 9(s5): 29-68.

Kazi, S. (2020), 'Bangladesh's 50 Years Journey to Climate Resilience'. https://blogs.worldbank.org/ endpovertyinsouthasia/bangladeshs-50-years-journey-climate-resilience

Kelman, I. (2020), Disaster by Choice, 1st edn (Oxford, Oxford University Press).

Kelman, I. \& Ahmed, B. (2020), 'Bangladesh has Saved Thousands of Lives from a Devastating Cyclone-Here's How'. https://theconversation.com/ bangladesh-has-saved-thousands-of-lives-from-a-devastating-cyclone-heres-how-139903

Kelman, I., Ahmed, B., Esraz-Ul-Zannat, M., Saroar, M.M., Fordham, M. \& Shamsudduha, M. (2018), 'Warning Systems as Social Processes for Bangladesh Cyclones', Disaster Prevention and Management, 27: 370-9. https://doi.org/10.1108/DPM-12-2017-0318

Khalil, G.M. (1993), 'The Catastrophic Cyclone of April 1991: Its Impact on the Economy of Bangladesh', Natural Hazards, 8: 263-81. 
Kirschbaum, D., Kapnick, S.B., Stanley, T. \& Pascale, S. (2020). 'Changes in extreme precipitation and landslides over High Mountain Asia', Geophysical Research Letters 47, e2019GL085347. https:// doi.org/10.1029/2019GL085347

Kulp, S.A. \& Strauss, B.H. (2019), 'New Elevation Data Triple Estimates of Global Vulnerability to Sea-level Rise and Coastal Flooding', Nature Communications, 10: 4844. https://doi.org/10.1038/ s41467-019-12808-z

Mahala, B.K., Nayak, B.K. \& Mohanty, P.K. (2015), 'Impacts of ENSO and IOD on Tropical Cyclone Activity in the Bay of Bengal', Natural Hazards, 75: 1105-25.

Mbaye, K. (2017), 'Climate Change, Natural Disasters, and Migration', IZA World of Labor: 346. doi: 10.15185/izawol.346

Munir, M.H. (2019), 'Bangladesh Needs to Fight Against Illicit Finance Flow and to Achieve SDGs', report. www.socialwatch.org/node/18286

NASA (2020), 'Global Climate Change: Vital Signs of the planet'. https://climate.nasa.gov/

NPDM (2021), National Plan for Disaster Management 2021-2025, Action for Disaster Risk Management Towards Resilient Nation (Ministry of Disaster Management and Relief, Government of Bangladesh). http://nda.erd.gov.bd/files/1/Publications/Sectoral Policies and Plans/

O'Keefe P., Westgate K. \& Wisner B. (1976), 'Taking the Naturalness Out of Natural Disasters', Nature, 260: 566-7.

Oppenheimer, M., Glavovic, B.C., Hinkel, J., Wal, R.v.d., Magnan, A.K., Abd-Elgawad, A., Cai, R., Cifuentes-Jara, M., DeConto, R.M., Ghosh, T., Hay, J., Isla, F., Marzeion, B., Meyssignac, B. \& Sebesvari, Z. (2019), Chapter 4: Sea Level Rise and Implications for Low Lying Islands, Coasts and Communities (Cambridge, Intergovernmental Panel on Climate Change). www.ipcc.ch/srocc/ chapter/chapter-4-sea-level-rise-and-implications-for-low-lying-islands-coasts-and-communities/

Paul, B.K. (2005), 'Evidence against Disaster-induced Migration: The 2004 Tornado in North-central Bangladesh', Disasters, 29: 370-85.

Paul, B.K. (2009), 'Why Relatively Fewer People Died? The Case of Bangladesh's Cyclone Sidr', Natural Hazards, 50: 289-304.

Prodhan, F.A., Zhang, J., Bai, Y., Sharma, T.P.P. \& Koju, U.A. (2020), 'Monitoring of Drought Condition and Risk in Bangladesh Combined Data From Satellite and Ground Meteorological Observations', IEEE Access, 8: 93264-82. https://ieeexplore.ieee.org/document/9088956

Rigaud, K.K., Sherbinin, A., Jones, B., Bergmann, J., Clement, V., Ober, K., Schewe, J., Adamo, S., McCusker, B., Heuser, S. \& Midgley, A. (2018), Groundswell: Preparing for Internal Climate Migration (Washington, DC, The World Bank). https://openknowledge.worldbank.org/ handle/10986/29461

Sen, A. (1981), 'Ingredients of Famine Analysis: Availability and Entitlements', The Quarterly Journal of Economics, 96: 433-64. www.jstor.org/stable/1882681

Shamsudduha, M., Joseph, G., Haque, S.S., Khan, M.R., Zahid, A. \& Ahmed, K.M.U. (2020), 'Multihazard Groundwater Risks to Water Supply from Shallow Depths: Challenges to Achieving the Sustainable Development Goals in Bangladesh', Exposure and Health, 12: 657-70. https://doi. org/10.1007/s12403-019-00325-9

UNDRR (2020), Human Cost of Disasters: An Overview of the Last 20 Years 2000-2019 (Geneva, UN Office for Disaster Risk Reduction (UNDRR)).

WMO (2020), World's Deadliest Tropical Cyclone was 50 Years Ago (Geneva, World Meteorological Organization (WMO)). https://public.wmo.int/en/media/news/ world $\% \mathrm{E} 2 \% 80 \% 99$ s-deadliest-tropical-cyclone-was-50-years-ago

WMO (2021), New Climate Predictions Increase Likelihood of Temporarily Reaching $1.5{ }^{\circ} \mathrm{C}$ in Next 5 Years (Geneva, World Meteorological Organization (WMO)). https://public.wmo.int/en/media/ press-release/new-climate-predictions-increase-likelihood-of-temporarily-reaching-15- ${ }^{\circ} \mathrm{c}-\mathrm{next}-5$

World Bank (2021), Poverty Headcount Ratio at National Poverty Lines (\% of Population). https://data. worldbank.org/indicator/SI.POV.NAHC 
Zaman, S., Sammonds, P., Ahmed, B. \& Rahman, T. (2020), 'Disaster Risk Reduction in Conflict Contexts: Lessons Learned from the Lived Experiences of Rohingya Refugees in Cox's Bazar, Bangladesh', International Journal Disaster Risk Reduction, 50: 101694. https://doi.org/10.1016/j. ijdrr.2020.101694

To cite the article: Peter Sammonds, Mohammad Shamsudduha and Bayes Ahmed (2021), 'Climate change driven disaster risks in Bangladesh and its journey towards resilience', Journal of the British Academy, 9(s8): 55-77.

DOI https://doi.org/10.5871/jba/009s8.055

Journal of the British Academy (ISSN 2052-7217) is published by

The British Academy, 10-11 Carlton House Terrace, London, SW1Y 5AH

www.thebritishacademy.ac.uk 